\title{
Isolation, identification and molecular characterization of Ralstonia solanacerum isolates collected from Southern Karnataka
}

\author{
H. M. Shweta \\ Department of Plant Pathology, UAS, GKVK, Bangalore -560065 (Karnataka), India \\ M. K. Prasanna Kumar \\ Department of Plant Pathology, UAS, GKVK, Bangalore -560065 (Karnataka), India \\ Kalavati Teli* \\ Department of Plant Pathology, UAS, GKVK, Bangalore -560065 (Karnataka), India \\ Bharath Kunduru \\ Department of Plant Pathology, UAS, GKVK, Bangalore -560065 (Karnataka), India \\ B. S. Chandra Shekar \\ Department of Plant Pathology, UAS, GKVK, Bangalore -560065 (Karnataka), India \\ *Corresponding author. E-mail: agriunit.kalavati@gmail.com
}

\begin{abstract}
Bacterial wilt caused by Ralstonia solanacearum, is the major threat to tomato cultivation in all tomato growing areas of Karnataka. $R$. solanacearum was isolated from the infected host plants collected from different locations of southern Karnataka. The identity of the isolates was established using morphological, biochemical, and molecular analysis using species specific PCR primers. The race and biovar specificity of pathogen was determined through pathogenicity test on different host plants and the ability of isolates to use carbohydrates, respectively. Phylotype classification was done by phylotype specific multiplex PCR using phylotype specific primers. All the bacterial isolates showed the characteristic creamy white fluidal growth with pink centre on the Tetrazolium chloride medium. Further, the isolates amplified at $280 \mathrm{bp}$, which confirmed the identity of pathogen as Ralstonia solanacearum. Our results showed that all isolates belonged to Race 1 of the pathogen. Among different isolates obtained, four isolates each were identified to be Biovar III and Biovar IIIA, repectively, while two isolates were identified as Biovar IIIB. All the ten isolates were affiliated to Phylotype I of Ralstonia solanaceraum species complex. These findings may help in devising the management practices for bacterial wilt of tomato in southern Karnataka.
\end{abstract}

Keywords: Bacterial wilt, Biovar, Phylotype, Race, Ralstonia solanacearum

\section{Article Info}

DOI:10.31018/jans.v10i3.1747

Received: May 24, 2018

Revised: July 10, 2018

Accepted: July 25, 2018

\section{How to Cite}

Shweta, H.M. et al. (2018). Isolation, identification and molecular characterization of Ralstonia solanacerum isolates collected from Southern Karnataka. Journal of Applied and Natural Science, 10(3): $886-893$

\section{INTRODUCTION}

Ralstonia solanacearum (Smith, 1896; Yabuuchi et al., 1995), is a soil borne, aerobic, gramnegative, rod shaped, non-spore forming bacterial plant pathogen and a serious threat to production of many crop plants around the world (Agrios, 1997). The bacterium invades vascular tissues and causes wilt disease in plants. It is the causal agent of moko disease of banana, brown rot of potato, bacterial wilt or southern wilt of tomato, tobacco, eggplant and some ornamental plant species (Stevenson et al., 2001). Bacterial wilt is a common bacterial plant disease in tropical, subtropical, and some temperate regions of the world (Fegan and Prior, 2005). The species, R. solanacearum has a very broad host range, but variability exists among the species with respect to their race specificity and host preference. Generally, the pathogen infects hundreds of plant spe- cies encompassing 44 families (Hayward, 1991), including economically-important plant species of Solanaceae or nightshade family (Stevenson, et al., 2001).

The soil-borne nature of the bacterium makes it difficult to control the pathogen due to the interaction of environmental factors and high pathogen diversity. Crop cultivars resistant to this pathogen were available in few plant species, however, their resistance is limited to only few strains of $R$. solanaceraum (Buddenhagen et al., 1962; Hayward, $1964,1994)$. The pathogen is highly diverse, represented by hundreds of genetically distinct isolates and hence, $R$. solanacearum is considered as a species complex; a heterogeneous group of related strains (Fegan and Prior, 2005). The species is currently classified into five races based on its host specificity and grouped into six biovars with respect to carbohydrate utilization (Hayward, 1964). Race 1 of this pathogen is the most abun- 
dant and widely distributed throughtout the world, which affects solanaceous crops and other plants species from several botanical families. Race 2 is mainly confined to tropical areas and causes the Moko disease of banana in South America, Philippines, Hawaii and Asia. This race also infects Heliconia sp. and other ornamental plant species of the family Musaceae. Race 3 usually occurs in tropical areas with higher altitude and temperate climate and affects mainly potato, tomato, and to a lesser extent, other hosts such as solanaceous weeds and geranium. Race 4 was reported on ginger in Philippines, while Race 5 was reported on mulberry in China (Buddenhagen et al., 1962). Several studies were earlier conducted to isolate this pathogen from different host species and characterize the diversity within species in terms of race and biovar specificity using ERIC-PCR and BOX-PCR (Gilson et al., 2012). Phylogenetic analysis of sequences of part of Egl and MutS genes revealed predominance of phylotype II in Brazil. Seventy seven bacterial strains isolated from wilted bell pepper plants from north eastern Brazil were identified as Ralstonia solanacearum using multiplex PCR. The strains were further analysed to characterize their biochemical, physiological, and molecular diversities (Garcia et al., 2013).

A phylogenetic classification scheme based on the study of partial sequences of the spacer region, 16S-23S rDNA (ITS) divides the species complex into four phylotypes (Poussier et al., 2000) corresponding to the four genetic clusters associated with their respective geographical origin. Phylotype I includes strains originated in Asia; phylotype II strains were originated from America; strains included under phylotype III were originated in Africa; and phylotype IV includes strains native to Indonesia (Fegan and Prior, 2005). The present study was conducted to isolate $R$. solanacearum from different host plants collected from different locations of southern Karnataka and characterize the race, biovar and phylotype specificity within the species to study the taxonomic diversity of the species in the region.

\section{MATERIALS AND METHODS}

Collection and isolation of $R$. solanacearum from wilt affected Solanaceae plants: Infected host plants viz. tomato, brinjal, chilli, capsicum, and potato with typical symptoms of bacterial wilt were collected from different parts of southern Karnataka (Table 1). The disease in infected plants was diagnosed using ooze test (Sujeet Kumar et al., 2017). The disease confirmed vascular tissues of infected plants were processed for isolation of pathogen on Triphenyltetrazolium Chloride (TZC) medium (Peptone-10g; Casein hydrolylate-1g; Dextrose-5g; Agar-15g; $5 \mathrm{ml}$ of $1 \%$ TZC ; Distilled water-1000 ml) using serial dilution meth- od. Discoloured vascular tissues were cut into small pieces measuring $4-5 \mathrm{~mm}$ length and surface sterilized using $0.1 \%$ sodium hypochlorite $(\mathrm{NaOCl})$ solution for $30 \mathrm{sec}$. Subsequently, the tissue bits were repeatedly washed with sterile double distilled water to remove traces of sodium hypochlorite, if any. The surface sterilized bits were suspended in a test tube containing $10 \mathrm{ml}$ of sterile distilled water for $10 \mathrm{~min}$. After the bacterial cells oozed out from the cut ends of tissue bits, the bacterial suspension in test tube was serially diluted in $9 \mathrm{ml}$ of sterile water blanks. About $100 \mu \mathrm{l}$ of bacterial suspension from the serial dilution was uniformly streaked onto the culture plates containing solidified TZC medium. The inoculated culture plates were incubated at $32^{\circ} \mathrm{C}$ for 48 hours.

Characterization of $R$. solanacearum isolates: The virulent isolates (colonies with characteristic red or pink centre and whitish margin) obtained from the infected tomato, brinjal, chilli, capsicum and potato plants were subjected to morphological, physiological, cultural, biochemical and pathogenicity studies as established by previous reports (Kelman, 1954; Buddenhagen et al., 1962; Schaad 1992).

Morphological and cultural characterization of $\boldsymbol{R}$. solanacearum: The pathogen was initially identified based on the colony morphology viz. shape, size, pigmentation and mucoidness. The morphological characteristics such as cell shape, gram reaction and capsule staining were done by following the descriptions given by Anonymous (1957), Kelman (1954), Bradbury (1970) and Schaad (1992).

Gram staining: A loop full of bacterial culture was smeared on to clean glass slide, air dried and heat fixed. Crystal violet was flooded for $1 \mathrm{~min}$, the slide was washed with distilled water and flooded with iodine solution for $1 \mathrm{~min}$. The iodine solution was washed with $95 \%(\mathrm{v} / \mathrm{v})$ ethyl alcohol and subsequently with distilled water, drained and counter stained with safranin $1 \mathrm{~min}$. The slide was washed with distilled water, air dried and examined under microscope using oil immersion objective lens.

Physiological and biochemical characterization of $\boldsymbol{R}$. solanacearum: Physiological and biochemical tests viz. starch hydrolysis, nitrate reduction, oxidase and $\mathrm{KOH}$ solubility test were carried out as per the methods described in the Manual of Microbial methods (Anonymous, 1957) and laboratory guide for identification of Plant Pathogenic Bacteria (Schaad, 1992).

Catalase test: A loop full of bacterial culture was smeared on a clean glass slide and added with few drops of hydrogen peroxide (20 volumes). Production of gas bubbles indicates a positive reaction, which is related tot the presence of aerobic and facultative anaerobic bacteria.

Oxidase test: Fresh bacterial cultures grown on nutrient agar media with $1 \%(\mathrm{w} / \mathrm{v})$ glucose were 
patched onto a filter paper moistened with a fresh oxidase reagent $(1 \% \mathrm{w} / \mathrm{v}$ aqueous solution of $\mathrm{N}, \mathrm{N}, \mathrm{N}$ ',N'-tetramethyl-p-phenylenediamine dihydrochloride) using a wooden stick. A purple reaction in $30 \mathrm{sec}$ confirms the test as positive. This test is used to detect the presence of cytochrome C oxidase (oxidase positive).

Nitrate agar test: The nitrate agar test for the ten isolates was conducted as per the previous established procedure (http://www.asmscience.org/ content/education/protocol/protocol.3660). In brief, this test confirms the ability of the bacterium to reduce nitrates into nitrites.

KOH solubility test: A loop full of the bacterial culture was smeared on a clean glass slide and 23 drops of $3 \%(\mathrm{w} / \mathrm{v}) \mathrm{KOH}$ was added. The colony of the test strain was stirred in to the solution with clean loop for 5 to $10 \mathrm{sec}$. When the solution was viscous enough and sticks to the loop causing a thin strand of slime or thread, then the test is rendered positive ( $\mathrm{KOH}$ soluble).

Pathogenicity test for $\boldsymbol{R}$. solanacearum: Tomato, brinjal, chilli, capsicum, and potato seedlings were raised in polythene bags containing sterilized soil mixed with essential plant nutrients. The roots of 20 days old seedlings of tomato, brinjal, chilli, and capsicum were washed in water and few tertiary roots were sheared with sterilized scissors. The injured roots of the seedlings were dipped in the bacterial suspension (OD at $\mathrm{A}_{480} \mathrm{~nm}=1.0$ ) separately for each isolate of $R$. solanacearum for $10 \mathrm{~min}$ and the treated seedlings were transplanted to plastic bags containing sterilized soil. For potato seedlings, the bacterial suspension was drenched around the root zone.

Race determination: The race specificity of $R$. solanacearum isolates was determined through artificial inoculation of pathogen to the test plants. All the ten isolates of $R$. solanacearum were multiplied overnight in TZC broth and subsequently inoculated onto tomato, brinjal, potato, ginger, banana, and mulberry plants. The bacterial suspension was adjusted to cell concentration of $5 \times 10^{5} \mathrm{cfu} / \mathrm{ml}$ using spectrophotometer at wave length of $480 \mathrm{~nm}$, with an $\mathrm{OD}$ value equivalent to $\mathrm{A}_{480} \eta \mathrm{nm}=0.8$ to 1.0

Determination of isolates into biovars: Biovars of $R$. solanacearum are primarily differentiated according to their ability to oxidize disaccharides viz. cellobiose, lactose, and maltose and utilize sugar alcohols such as dulcitol, mannitol, and sorbitol (Hayward, 1964).

The three sugars viz. cellobiose, lactose, and maltose and three sugar alcohols viz. dulcitol, mannitol, and sorbitol were supplemented separately to a basal medium $\left(\mathrm{NH}_{4} \mathrm{H}_{2} \mathrm{PO}_{4}-1.2 \mathrm{~g}\right.$; $\mathrm{MgSO}_{4} .7 \mathrm{H}_{2} \mathrm{O}-0.24 \mathrm{~g}$; KCl-0.24 g; Peptone-1 to 2 g; $\mathrm{KOH}-3 \%(\mathrm{w} / \mathrm{v})$; Distilled water-1000 $\mathrm{ml}$ ) at the rate of $0.03 \mathrm{~g} /$ litre. The $\mathrm{pH}$ of the basal medium was adjusted to 7.2 using $40 \%(w / v) ~ N a O H$ solu- tion until olivaceous green colour was observed in the basal medium. Bromophenol blue was added to the basal medium as an indicator for oxidation reaction (colour change).

The basal medium with bromophenol blue was autoclaved at $121^{\circ} \mathrm{C}$ for $15 \mathrm{~min}$ and cooled to $45^{\circ}$ C. Subsequently, the six sugar solutions were added to each flask separately and mixed thoroughly to get uniform distribution of sugar solution in the basal medium. Aliquots of $5 \mathrm{ml}$ from each sugar supplemented basal medium was separately dispensed into 10 sterile Durham's tubes (6 inch) under aseptic conditions. The tubes containing the aliquots were seperately inoculated with $20 \mu$ of bacterial suspension of ten isolates. The inoculated tubes were incubated at $30^{\circ} \mathrm{C}$ and the culture media were examined at $3,7,14$ days for change in $\mathrm{pH}$ from basic to acidic producing yellow color from top downward.

Molecular characterization of Ralstonia solanacearum

Genomic DNA extraction: The genomic DNA from the bacterial cells was isolated using AMpurE Bacterial gDNA Mini Spin kit (\#AMRK016, Amnion Biosciences). The bacterial cells were collected from 24 hour nutrient broth cultures by centrifugation for $2 \mathrm{~min}$ at $12000 \mathrm{rpm}$. The pelleted cells were processed as per manufacturer's instruction for isolation of genomic DNA from bacterial cells. The extracted DNA was quantified using $0.8 \%(\mathrm{w} /$ v) agarose gel.

PCR for confirmation of $\boldsymbol{R}$. solanacearum: The $16 \mathrm{~S}$ rDNA of all isolates were amplified by using universal specific primer set of $759 / 760$ as described by Sagar et al. (2014). Each PCR reaction consisted of $50 \mu \mathrm{l}$ mixture containing primers (20 pmols of 759/760 each), PCR master mix consisting of $\mathrm{MgCl}_{2}(2 \mathrm{mM})$, dNTP's $(200 \mu \mathrm{M})$, Taq polymerase (2.5 U), template DNA (50 ng), and molecular grade water. The reaction mixture was amplified in Thermal cycler (Eppendorf) for 35 cycles after an initial denaturation at $96^{\circ} \mathrm{C}$ for $5 \mathrm{~min}$. Each cycle consisted of $15 \mathrm{sec}$ at $94^{\circ} \mathrm{C}, 30 \mathrm{sec}$ at $59^{\circ} \mathrm{C}$, $72^{\circ} \mathrm{C}$ for $30 \mathrm{sec}$ and final extension for $10 \mathrm{~min}$ at $72^{\circ} \mathrm{C}$. All the PCR products were electrophoresed using $2 \%(\mathrm{w} / \mathrm{v})$ agarose gel for confirmation of template amplified.

Molecular analysis of 16S rDNA: The 16S rDNA fragments of bacterial DNA were amplified using Fd1 forward (GAGTTTGATCCTGGTCA) and Rp2 reverse (ACGGCTACCTTGTTACGACTT) primers. $\mathrm{PCR}$ reaction mixture $(50 \mu \mathrm{l})$ contained $20 \mathrm{pmol}$ of each primer, $50 \mathrm{ng}$ of genomic DNA, 1X Taq DNA polymerase buffer, $1 \mathrm{U}$ of TaqDNA polymerase, $0.2 \mathrm{mM}$ of each dNTPs and $1.5 \mathrm{mM}$ of $\mathrm{MgCl}_{2}$. The thermal cycling program consisted of initial denaturation at $94{ }^{\circ} \mathrm{C}$ for 3 min followed by 35 cycles with denaturation at $94{ }^{\circ} \mathrm{C}$ for $1 \mathrm{~min}$, annealing at $46^{\circ} \mathrm{C}$ for $30 \mathrm{sec}$ and extension at $72^{\circ} \mathrm{C}$ for $4 \mathrm{~min}$, with a final extension at $72{ }^{\circ} \mathrm{C}$ for $10 \mathrm{~min}$. Amplifi- 
cation was performed in a DNA thermal cycler (Eppendorf). The purified PCR products were subjected to Sanger dideoxy sequencing at Amnion Biotech Pvt. Ltd. (Bangalore, India). The DNA sequences were compared with $\mathrm{NCBI}$ database using BLASt tool and the isolates were identified based on the nearest homology search results. The phylogenetic tree was constructed for bacterial isolates based on the closest relative organisms obtained in NCBI query using Mega 6 software.

Phylotype identification: Phylotype identification (Prior and Fegan, 2005) was done using Phylotype specific multiplex PCR (Pmx-PCR). The reaction mixture consisted of 25 ul final volume, containing 2X Master mix (PCR buffer, $1.5 \mathrm{mM}$ $\mathrm{MgCl}_{2}, 200 \mathrm{uM}$ of each dNTP, $50 \mathrm{mM} \mathrm{KCl}, 10 \mathrm{mM}$ Tris- $\mathrm{HCl}$ and $1.25 \mathrm{U}$ of Taq DNA polymerase), 6 pmoles of the primers, Nmult: 21:1F, Nmult: 21:2F, Nmult:22:InF, 18 pmoles of the primer Nmult:23:AF and 4 pmoles of the primers 759 and 760 (Opine et al., 1997) Table.2. The following cycling programme was used in a thermal cycler (Eppendorf): $96^{\circ} \mathrm{C}$ for 5 minute and then cycled through 30 cycles of $94^{\circ} \mathrm{C}$ for $15 \mathrm{~s}, 59^{\circ} \mathrm{C}$ for $30 \mathrm{~s}$ and $72^{\circ} \mathrm{C}$ for $30 \mathrm{~s}$, followed by a final extension period of 10 minute at $72^{\circ} \mathrm{C}$. The amplified PCR products were electrophoresed on $2 \%(\mathrm{w} / \mathrm{v})$ agarose gel and visualized on a UV-trans illuminator.

\section{RESULTS AND DISCUSSION}

Collection, isolation and characterization of the $R$. solanacearum isolates: The laterally dissected infected plants showed brownish discolouration of roots and stem portion just above the collar region. The disease was confirmed through ooze test (Plate.1) of infected tissues of host plants. Milky white bacterial ooze was observed from the cut ends of infected tissues placed in sterile distilled water (Vanitha et al., 2009). The bacterial colonies of all the 10 isolates on TZC medium were well separated, irregular with smooth and dull white margin, and characteristic pink to red center. TZC medium is commonly used to differentiate the virulent and avirulent strains of $R$. solanacearum based on the morphological characteristics. All the isolates in the present study exhibited the typical characteristics of virulent strains (Plate.2) i.e. highly fluidal, round to irregular colonies with white margin with pink centre. Gram reaction identified that all the isolates were gram negative (reddish pink) with straight and slightly curved rod shaped cells, which is the characteristic feature of the pathogen (Smith, 1896).

Physiological and biochemical tests: The results of physiological and biochemical tests on the ten isolates of $R$. solanacearum were presented in Table.3. The results obtained in the present study were concurrent with the previous reports on the pathogen. The present study showed that all iso-

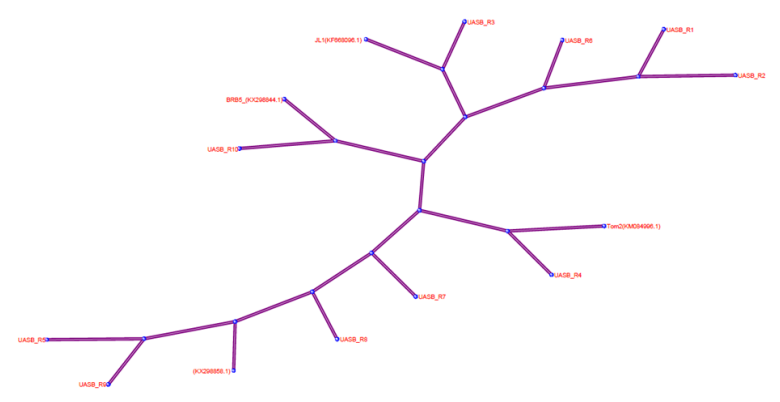

Fig.1. Phylogenetic tree of ten isolates of $R$. solanacearum.

lates were positive for oxidase test (Ahmed et al., 2013), which produced purple colour when the bacterial mass was rubbed on filter paper impregnated with oxidase reagent and this proved the aerobic nature of the pathogen. All the ten isolates of $R$. solanacearum obtained in the present study were found positive for nitrate test. Makhlouf and Hamedo (2013) also reported positive results for nitrate test with six isolates of $R$. solanacearum obtained from infected tomato plants. Positive reaction for nitrate test indicated the ability of bacteria to convert nitrates into nitrites. Similarly, all isolates in the present study were identified positive for the $\mathrm{KOH}$ solubility test as they formed slime threads when the bacterial cultures were mixed with $3 \% \mathrm{KOH}$ solution. $\mathrm{KOH}$ test is a rapid and easy technique to distinguish the gram negative and gram positive bacteria as compared to the conventional Gram staining (Suslow et al., 1982). Shahbaz et al. (2015) isolated R. solanacearum from infected chilly plants and identified the isolates positive for catalase test.

Pathogenicity test: $R$. solanacearum is a soil borne pathogen and has both virulent and avirulent strains. It is essential to determine pathogenicity of isolates in order to confirm their virulence. The pathogenicity test for all the test isolates in the present study using root dip inoculation method (Avinash and Umesha, 2013) produced typical wilting symptoms in tomato plants within three weeks after treatment. The treated plants exhibited loss of turgidity, drooping of leaves and sudden wilting symptoms. Re-isolation of pathogen from the wilted plants yielded bacterial colonies that were similar to the original colonies used for inoculation. This confirmed the virulence of all isolates of $R$. solanacearum obtained in the present study. Thus on the basis of results obtained from morphological, cultural, biochemical, and pathogenicity tests, all the ten isolates obtained from different host plants collected from southern Karnataka were identified as $R$. solanacearum.

Determination of race specificity: The ten isolates of $R$. solanacearum were cross infected to different hosts and all the test isolates produced highly virulent reaction on tomato, brinjal, and po- 
Shweta, H.M. et al. / J. Appl. \& Nat. Sci. 10 (3): 886 - 893 (2018)

Table 1. Infected host plants collected from different parts of Southern Karnataka.

\begin{tabular}{llll}
\hline Primers & Sequence (5'-3') & Size (bp) & Specificity \\
\hline Nmult:21:1F & CGTTGATGAGGCGCGCAATTT & 144 & Phylotype I \\
Nmult:21:2F & AAGTTATGGACGGTGGAAGTC & 372 & Phylotype II \\
Nmult:22:InF & ATTGCCAAGACGAGAGAAGTA & 91 & Phylotype III \\
Nmult:23:AF & ATTACSAGAGCAATCGAA & 213 & Phylotype IV \\
Nmult:22:RR & TCGCTTGACCCTATAACGAGTA & NA & All phylotypes \\
\hline
\end{tabular}

Table. 2. Primers used for phylotype characterization.

\begin{tabular}{llll}
\hline S. $\mathbf{N}$. & Host & Location & Isolate designation \\
\hline 1 & Tomato & GKVK, Bengaluru & UASBR1 \\
2 & Brinjal & GKVK, Bengaluru & UASBR2 \\
3 & Brinjal & Mandya & UASBR3 \\
4 & Tomato & Devanahalli (Sadhalli) & UASBR4 \\
5 & Brinjal & Doddaballapura & UASBR5 \\
6 & Tomato & Tumkur (Chikkanayakaahalli) & UASBR6 \\
7 & Tomato & Hassan (Arasikere) & UASBR7 \\
8 & Chilli & Chikkaballapura & UASBR9 \\
9 & Capsicum & GKVK, Bengaluru & UASBR10 \\
10 & Potato & Chikkaballapura & \\
\hline
\end{tabular}

Table 3. Morphological and bio chemical characteristics of $R$. solanacearum isolated from different hosts.

\begin{tabular}{|c|c|c|c|c|c|c|}
\hline \multirow{2}{*}{$\begin{array}{l}\text { SI. } \\
\text { No. }\end{array}$} & \multirow{2}{*}{ Isolates } & \multicolumn{5}{|c|}{ Biochemical characteristics } \\
\hline & & Gram staining & Oxidase & Nitrate agar & Catalase test & KOH solubility \\
\hline 1 & UASBR1 & Negative & + & + & + & + \\
\hline 2 & UASBR2 & Negative & + & + & + & + \\
\hline 3 & UASBR3 & Negative & + & + & + & + \\
\hline 4 & UASBR4 & Negative & + & + & + & + \\
\hline 5 & UASBR5 & Negative & + & + & + & + \\
\hline 6 & UASBR6 & Negative & + & + & + & + \\
\hline 7 & UASBR7 & Negative & + & + & + & + \\
\hline 8 & UASBR8 & Negative & + & + & + & + \\
\hline 9 & UASBR9 & Negative & + & + & + & + \\
\hline 10 & UASBR10 & Negative & + & + & + & + \\
\hline
\end{tabular}

Table 4. Classification of $R$. solanacearum isolates into biovars.

\begin{tabular}{|c|c|c|c|c|c|c|c|c|}
\hline \multirow{2}{*}{ SI. No. } & \multirow{2}{*}{ Isolates } & \multicolumn{3}{|c|}{ Disaccharides } & \multicolumn{3}{|c|}{ Sugar alcohols } & \multirow{2}{*}{ Biovar } \\
\hline & & Cellobiose & Maltose & Lactose & Mannitol & Dulcitol & Sorbitol & \\
\hline 1 & UASBR1 & + & + & + & + & - & + & IIIA \\
\hline 2 & UASBR2 & + & + & - & + & - & + & IIIB \\
\hline 3 & UASBR3 & + & + & - & + & - & + & IIIB \\
\hline 4 & UASBR4 & + & + & + & + & + & + & III \\
\hline 5 & UASBR5 & + & + & + & + & + & + & III \\
\hline 6 & UASBR6 & + & + & + & + & - & + & IIIA \\
\hline 7 & UASBR7 & + & + & + & + & - & + & IIIA \\
\hline 8 & UASBR8 & + & + & + & + & + & + & III \\
\hline 9 & UASBR9 & + & + & + & + & - & + & IIIA \\
\hline 10 & UASBR10 & + & + & + & + & + & + & III \\
\hline
\end{tabular}

tato with characteristic wilt symptoms in $15-20$ days of inoculation. None of the test isolates were able to infect the other plant species such as banana, ginger, and mulberry. Based on the virulence on different hosts, the test isolates used in the present study were identified as race 1 . Similar results were reported by Prasanna Kumar et al. (2012) on prevalence of 57 isolates of $R$. solanacearum belonging to race 1 collected from different agro-climatic zones of India and causing wilt on different host plants viz. tomato (Solanum lycopersicum), brinjal (Solanum melongena), potato (Solanum tuberosum), bird of paradise (Strelitzia reginae), ginger (Zingiber officinale), chilli (Capsicum annuum), davana (Artemisia pallens), and coleus (Coleus forskohlii).

Buddenhagen et al. (1962) divided the R. solanacearum in to three races. Race 1 infects majority of the solanaceous plants including tomato, tobacco, pepper and other plants including some weeds. However, race 2 causes wilt of triploid banana (Musa spp.) and Heliconia spp. Race 3 affects potato and tomato but is weakly virulent on other solanaceous crops. Later, Aragaki and Quinon (1965) reported race 4 from infected ginger in the Philippines. He et al. (1983) reported race 5 from mulberry in China. The five races described so far differ in their host range, geographical distri- 


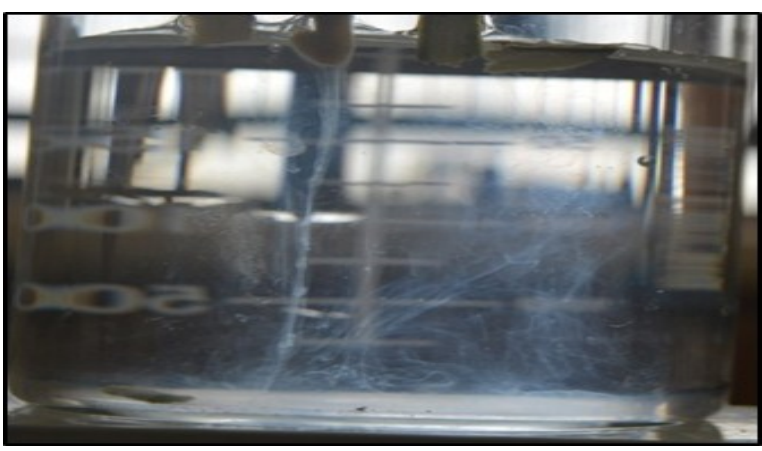

Plate.1. Oozing of bacterial cells from infected tomato plant.

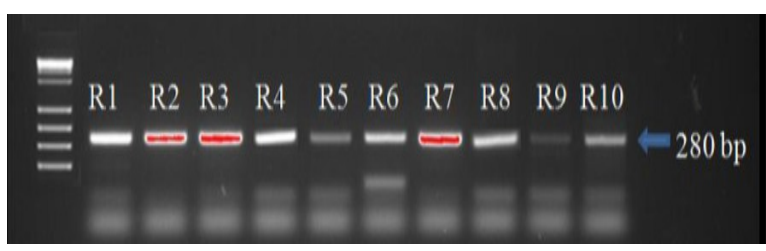

Plate. 3. Identification of isolates of $R$. solanacearum by using specific primers.

bution, and ability to survive under different environmental conditions (French, 1986). Prevalence of race 1 in India is due to its wide adaptability, although race 3 was reported on potato in northern India, it was not reported in southern India.

Biovar determination: Hayward (1964) classified different strains of $R$. solanacearum in to five biovars based on their ability to utilize sugars and alcohols. These are essential for bacteria as it contributes to the normal functioning of the cell. The strains of $R$. solanacearum are known to show variation in their ability to utilize alcoholic sugars and disaccharides (Prasanna Kumar, 2004). This variability gives an indication of their host adoptability by utilizing the specific sugars.

The biovar classification of the ten isolates used in the present study was presented in Table.4. In this study, four isolates of $R$. solanacearum (UASBR4, UASBR5, UASBR8, and UASBR10) were categorized into biovar III, which utilized all the six sugars and alcoholic sugars as evidenced by the colour change of bromophenol blue medium to yellow due to the production of acid in the medium (Venkatesh and Khan, 2000; Dhital et al., 2001). Prasanna Kumar (2004) also reported the prevalence of biovar III in India. Four isolates viz. UASBR1, UASBR6, UASBR7, and UASBR9) were grouped into biovar IIIA, which utilized only three disaccharides and two alcoholic sugars and failed to utilize one alcoholic sugar i.e. dulcitol (Deepa et al., 2003; Prasanna Kumar, 2004). The two isolates ,UASBR2 and UASBR3 were grouped in to biovar IIIB as they utilized two disaccharides and two alcoholic sugars and they could not utilize one alcoholic sugar and one disaccharide i.e. dulcitol and lactose, respectively (Prasanna Kumar, 2004; Chandrashekara et al.,

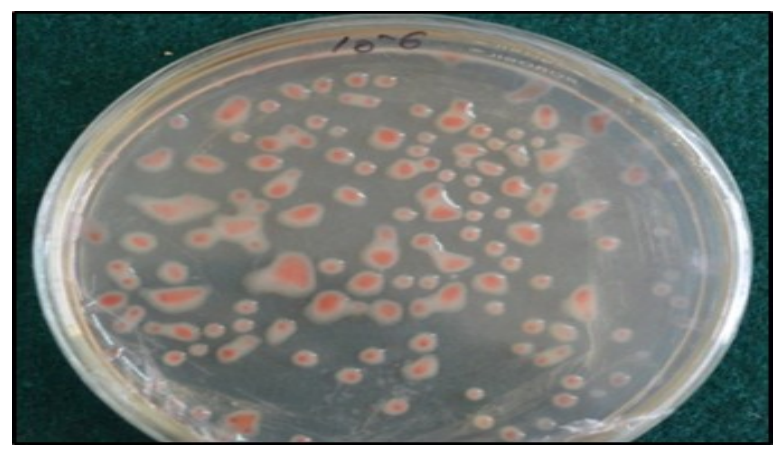

Plate.2. $R$. solanacearum colonies on TZC medium.

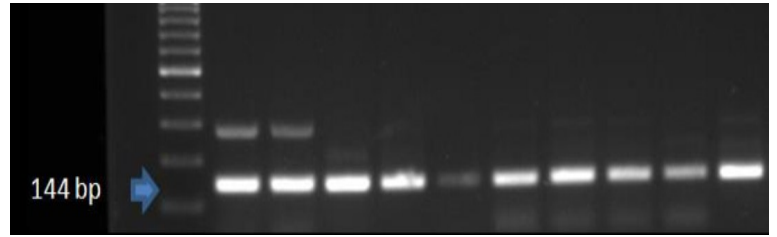

Plate. 4. Phylotype identification of isolates of $R$. solanacearum.

Abbreviation: Lane R1: Tomato (GKVK, Bengaluru); Lane R2: Brinjal (GKVK, Bengaluru); Lane R3: Brinjal (Mandya); Lane R4: Tomato (Sadhalli); Lane R5: Brinjal (Doddaballapura); Lane R6: Tomato (Chikkanayakaahalli); Lane R7: Tomato (Arasikere); Lane R8: Chilly (Chikkaballapura); Lane R9: Capsicum (GKVK, Bengaluru); Lane R10: Potato (Chikkaballapura)

2012). Different biovars could have lost their ability to utilize dulcitol or dulcitol and lactose or they might be non-essential for the growth and development. This may help the bacteria to survive in minimal nutrient condition, in the absence of hosts.

The inducible sugar utilization is mainly dependent on individual sugar utilization pathways which consists of transporters and catabolic enzymes whose expression is induced in the presence of sugars. The pathway has the feedback of positive and negative mechanisms, the positive feedback emerges from the sugar inducible expression of the transporters and leading to import of sugars while, negative feedback emerges from the sugar inducible expression of enzymes which lead to breakdown of sugars (Afroz et al., 2014). Hence, this could be one of the probable reasons for variation in sugar utilization by bacterial isolates, which may not have the particular sugar utilization pathway.

Identification of $R$. solanaearum by PCR amplification using specific primers: PCR amplication of isolates $R$. solanaearum using specific universal primers 759/760 yielded 280 bp product encoding $16 S$ rDNA in $R$. solanacearum confirming that all the 10 isolates belonged to $R$. solanacearum (Plate.3).

Amplification of 16S rDNA: The Sanger sequencing of $16 \mathrm{~S}$ rDNA also confirmed the identity 
of test isolates to be $R$. solanacearum as compared to their reference strains. Phylogenetic tree of $R$. solanacearum isolates was constructed based on the NCBI Genome Workbench tool (Figure.1). Based on their sequence similarities, the isolates R1, R2, R3, R6, and R10 formed a different branch in the phylogenetic tree, which showed similarity with reference strains BR-5 (KX298844.1) and JL-1(KF668096.1). The isolates R5 and R9 were found to be very distinct which held close homology with reference strain of accession no. KX298858.1 while, R4, R7 and R8 strains showed homology with Tom2 (KM084996.1) reference strain. The isolates $\mathrm{R} 1$, R2, R3, R6, and R10 were collected from Bengaluru (tomato), Bengaluru (brinjal), Mandya (brinjal), and Chikkaballapur (potato), respectively. The isolate, R5 was obtained from Doddaballapur (brinjal) whereas, R9 was collected from Bengaluru (capsicum). The isolates, R4 was collected from Devanahalli (tomato), R7 from Hassan (tomato) and R8 from Chikkaballapur (chilly). This results obtained in our present study indicated that the ten isolates collected showed variation with respect to their host and geographical distribution.

Phylotype characterization: Based on the origin and evolutionary nature, different strains of $R$. solanacearum were classified into four phylotypes. Phylotype I corresponds to the Asiatic origin, Phylotype II was native to America, Phylotype III contains strains from Africa and the Indian Ocean while, Phylotype IV contains strains from Indonesia. The PCR amplification resulted in a $\sim 144 \mathrm{bp}$ product from all the ten isolates of $R$. solanacearum (Plate.4) indicating that all the isolates belonged to phylotype I. The results of our study were in agreement with Sagar et al (2018).

\section{Conclusion}

The bacterial wilt is a widespread disease causing severe yield losses in many economically important solanaceous vegetables in India. Ten isolates of $R$. solanacearum were isolated from different hosts collected from different places of southern Karnataka were characterized through morphological, cultural, biochemical, molecular, and pathogenicity tests. Among the ten test isolates, four isolates were identified as biovar III, four isolates as biovar IIIA, and two isolates as biovar IIIB based on their ability to utilize disaccharides and alcoholic sugars. All ten isolates were identified as race I based on their host specificity. Multiplex PCR confirmed that all isolates collected in the present study belonged to phylotype I.

\section{REFERENCES}

1. Afroz, T., Biliouris, K., Kaznessis, y. and Beisel, C. L. (2014). Bacterial sugar utilization gives rise to distinct single-cell behaviours.Mol. Microbiol.,93(6):10931103

2. Agrios, G. N. (1997). Plant Pathology. $4^{\text {th }}$ ed. San Diego, California: Academic Press, Inc.409:431- 433

3. Ahmed, N. N., Islam, R. M., Hossain, M. A., Meah, M. B. and Hossain, M. M. (2013). Determination of races and biovars of Ralstonia solanacearum causing bacterial wilt disease of potato. J. Agril. Sci., 5(6):86-93

4. Anonymous (1957). Manual of Microbial Methods: (Ed.). Society of American Bacteriologists, McGraw, New York, 315.

5. Avinash, P. and Umesha, S. (2013). Identification and genetic diversity of bacterial wilt pathogen in Brinjal. Archi. Phytopathol. and Plant Prot., 29(4):1-9.

6. Bradbury, J. F. (1970). Isolation and preliminary study of bacteria from plants. Rev.PI. Pathol., 49: 213-218

7. Buddenhagen, I. W., Sequeira, L. and Kelman, A. (1962). Designation of races in Pseudomonas solanacearum. Phytopathol., 52: 726.

8. Chandrashekara, K. N., Prasanna Kumar, M. K., Deepa, M., Vani, A. and Khan, A. N. A. (2012). Prevalence of races and biotypes of Ralstonia solanacearum in India. J. PI. Prot. Res., 52(1): 53-58.

9. Deepa, J., Girija, D., Sally, K., Mathew, P. A., Nazeem, T. D. and Sukumara Varma. (2003). Detection of Ralstonia solanacearum race 3 causing bacterial wilt of solanaceous vegetables in kerala, using random amplified polymorphic DNA (RAPD) analysis. J. Trop. Agric., 41: 33-37.

10.Dhital, S. P., Thaveechai, N. and Shrestha, S. K. (2001). Characteristics of Ralstonia solanacearum strains of potato wilt disease from Nepal and Thailand. Nepal Agric. Res. J., Vol. 4(5): 42-47.

11.Fegan, M. and Prior, P. (2005). How complex is the Ralstonia solanacearum species complex? In: Allen C, Prior P, Hayward AC, editors. Bacterial wilt: the disease and the Ralstonia solanacearum species complex. St. Paul, MN: APS. 405-414.

12.French, E. R. (1996). Integrated control of bacterial wilt of potato. In: Bacterial Wilt Training Manual. International Potato Centre, Lima, Peru. Section 3: 4.

13. Hayward, A. C. (1964). Characteristics of Pseudomonas solannacearum. J. Appl. Bacteriol., 27:265-271.

14. Hayward, A. C. (1991). Biology and epidemiology of bacterial wilt caused by Pseudomonas solanacearum. Ann. Rev. Phytopathol., 29: 65- 87

15. He, L. Y., Sequeira, L. and Kelman, A. (1983). Characteristics of strains of Pseudomonas solanacearum from China. Pl. Dis., 67: 1357- 1361.

16.Makhlouf, A. H. and Hamedo, A. H. (2013). Suppression of bacterial wilt disease of tomato plants using some bacterial strains. J. Life Sci., 10(3): 1732-1741.

17.Opine, N., Tavner, F., Hollway, G., Wang, J. F., Li, T. H., Maghirang, R., Fegan, M., Hayward,A. C., Krishnapillai, V., Hong, W. F., Holloway, B. W. and Timmis, J. N. (1997). A novel method for development of species and strain specific DNA probes and PCR primers for identifying Bhurkholdria solanacearum. Asia Pac. J. Mol. Bio., 5: 19-30.

18.Poussier, S., Trigalet-Demery, D., Vandewalle, P., Goffinet, B., Luisetti, J. and Trigalet, A. (2000). Genetic diversity of Ralstonia solanacearum as assessed by PCR-RFLP of the hrp gene region. AFLP and 16S rRNA sequence analysis, and identification of an African subdivision. Microbiology.146:16791692 
19.Prasanna Kumar, M. K. (2004). Molecular characterization of the strains of Ralstonia solanacearum (Yabuuchi), ecology and integrated management of bacterial wilt of tomato. Ph.D. Thesis, Univ. Agric. Sci., Bengaluru, 235pp.

20.Prasanna Kumar, M. K., Chandrashekara, K. N., Deepa, M., Vani, A. and Khan, A. N. A. (2012). Finger printing of Ralstonia solanacearum isolates by Rep-PCR and RAPD. Pest Man. in Hortl. Ecosys., 18 (2): 179-187.

21.Sagar, V., Jeevalatha, A., Sarita Mian, Chakrabarti, S. K., Gurjar, M. S., Arora, R. K., Sharma, S., Bakade, R. R. and Singh, B. P. (2014). Potato bacterial wilt in India caused by strains of phylotype I, II and IV of Ralstonia solanacearum. Eur J Plant Pathol., 138 (1). Doi: 10.1007/s10658-013-0299-z.

22.Schaad, N.W. (1992). Laboratory guide for the identification of plant pathogenic bacteria, $2^{\text {nd }}$ ed. American phytopathol., 138pp.

23.Shahbaz, M. U., Mukhtar, T., Ul-Haque, M. I. and Begum, N. (2015). Biochemical and serological characterization of Ralstonia solanacearum associated with chilli seeds from Pakistan. Int. J. Agric. Biol., 17 (1):31-40.

24.Smith, E. F. (1896). A bacterial disease of the chilli, eggplant and Irish potato (Bacillus solanacearum) Nov. Sp., U. S. Dept. Agric. Div. Veg., Physiol. Path. Bull., 12: 1-28.

25.Stevenson, W.R., Loria, R., Franc, G.D. and Weingartner, D.P. Eds. (2001). Compendium of Potato Diseases, 2nd Ed. APS Press, St. Paul, MN.

26. Sujeet Kumar, Kedarnath, N. H., Rohini, I.B., Rangaswamy, K.T., Ramanjini Gowda, P.H. and Raghavendra Achari. (2017). Isolation and characterization of Ralstonia solanacearum causing bacterial wilt of Solanaceae crops. Int.J.Curr. Microbiol.App.
Sci., 6(5): 1173-1190. doi: https://doi.org/10.20546/ ijcmas.2017.605.128

27.Suslow, T. V., Schroth, M. N. and Isaka, M. (1982). Application of a rapid method for Gram differentiation of plant pathogenic and saprophytic bacteria without staining. Phytopathol., 72: 9117-918.

28.Venkatesh and Khan, A. N. A. (2000). Prevalence of races/biotypes of Ralstonia solanacearum and management of bacterial wilt of potato. In: Potato, Global Research and Development - 452-455. Indian Potato Association, Shimla.

29.Venkatesh (2000). Biology, ecology and integrated management of bacterial wilt of potato caused by Ralstonia solanacearum. Ph. D. Thesis, Univ. Agric. Sci., Bangalore.

30.Yabuuchi, E., Kosako, Y., Yano, I., Hotta, H. and Nishiuchi, Y. (1995). Transfer of two Burkholderia and an Alcaligenes species to Ralstonia gen. nov.: proposal of Ralstoniapicketii (Ralston, Palleroni \& Doudoroff 1973) comb. nov.Ralstonia solanacearum (Smith, 1896) comb. nov. and Ralstoniaeutropha (Davis, 1969). Microbiol. Immuno., 897-904.

31.Garcia, A. L., Lima, W. G., Souza, E.B., Michereff, S. J. and Mariano, R. L. R. (2013). Characterization of Ralstonia solanacearum causing bacterial wilt in bell pepper in the state of Pernambuco, Brazil. Journal of Plant Pathology. 95: 237-245.

32.Gilson, G., Costa, L. and Rodrigues L. M. R. ( 2012). Characterization of Ralstonia Solanacearum strains from Brazil using molecular methods and pathogenicity tests, Journal of Plant Pathology, 94: 505-516.

33.Vanitha, S. C., Niranjana. S. R., Mortensen, C. N., and Umesha, S. (2009). Bacterial wilt of tomato in Karnataka and its management by Pseudomonas fluorescens. Biocontrol. 54: 685-695. 